\title{
Effect of temperature on mortars with incorporation of phase change materials
}

\author{
Sandra Cunha*, José Aguiar, Fernando Pacheco-Torgal \\ University of Minho, Campus de Azurém, 4800-058 Guimarães, Portugal
}

\section{H I G H L I G H T S}

- Twelve different mortars were developed with phase change material incorporation.

- The aim of this study was evaluate the effect of the high temperatures on mortars.

- The exposure to high temperatures leads to a decrease in the mechanical strengths.

- The behavior to high temperatures of the PCM mortars is similar to reference mortars.

\section{A R T I C L E I N F O}

\section{Article history:}

Received 27 March 2015

Received in revised form 29 July 2015

Accepted 9 August 2015

\section{Keywords:}

Mortars

Phase change materials

Temperature effect

Mechanical properties

\begin{abstract}
A B S T R A C T
Mortars with incorporation of phase change materials (PCM) have the ability to regulate the temperature inside buildings, contributing to the thermal comfort and reducing the use of heating and cooling equipment. However, it is important that they present a good behavior when subjected to aggressive conditions. The main purpose of this study was the effect of high temperatures on mortars with PCM. It was observed that the exposure to high temperatures leads to a decrease in the flexural, compressive and adhesion strengths. However, the behavior of the mortar with PCM is similar to reference mortars.
\end{abstract}

(C) 2015 Elsevier Ltd. All rights reserved.

\section{Introduction}

The growing energy demand worldwide is an ever-increasing issue with regard to climate change and energy supply. The world consumes large amounts of fossil fuels that drive climate changes and empties the supplies of fossil fuels more rapidly. One method to benefit energy usage globally is to increase the energy efficiency of buildings [1]. It is important to remember that the European building sector is responsible for about $40 \%$ of the energy consumption [2]. A possible solution to face the increasing energy demand worldwide and reduce the negative environmental impacts is the higher utilization of environmentally friendly renewable energy technologies [1].

The incorporation of phase change materials (PCM) into construction materials has been proposed as a passive means of decreasing the overall heating and cooling demand of a building [3]. Thus, the incorporation of PCM in mortars for the interior

\footnotetext{
* Corresponding author.

E-mail addresses: sandracunha86@gmail.com (S.Cunha), aguiar@civil.uminho.pt (J. Aguiar), torgal@civil.uminho.pt (F. Pacheco-Torgal).
}

appears as a possible solution in an attempt to solve, or at least minimize, the massive energetic consumption related with buildings. The use of this material allows the regulation of frequency of temperatures fluctuations, keeping them closer to the desired temperature range for a longer period, using only solar energy as a resource, or at least reducing the need to use heating and cooling equipment.

The phase change materials possess the capability to alter its own state as function of the environmental temperature [4]. In other words, when the surrounding environmental temperature of PCM increases until the materials fusion point, it suffers a change from a solid state to a liquid state, absorbing and storing the heat energy from the environment. On the other hand, when the temperature decreases until the PCM solidification point, the material alters from the liquid state to solid state, releasing the previously stored energy to the environment. This application could be made in coating mortars of buildings, with advantage in the passive regulation of internal temperature with increase of thermal inertia [5].

The PCM is generally used encapsulated. There are two types of encapsulation: macroencapsulation and microencapsulation. The 
macroencapsulation is based in the introduction of PCM into tubes, panels or other large containers. It is usually done in containers with more than $1 \mathrm{~cm}$ in diameter and presents a better compatibility with the material, improving the handling in construction [6]. The microencapsulation consists on covering the material particles, with a material, usually a polymer, commonly known capsule, with dimensions between $1 \mu \mathrm{m}$ and $60 \mu \mathrm{m}[6,7]$. Recently, this problem of encapsulation was solved by using shape-stabilized PCM. These shape-stabilized PCM can be prepared by integrating the PCM into the supporting material. The shape-stabilized PCM are mainly classified as composite PCM and are usually fabricated by embedding PCM into shape stabilization supports such as high density polyethylene, styrene, butadiene, polymethacrylic acid, polystyrene resin, etc [8].

In the last years several studies were published related to construction materials with incorporation of PCM. The incorporation of PCM in gypsum plasterboard has been the subject of several studies performed, due to its low cost and various possibilities of application [9-12]. Darkwa et al. [11] investigated the behavior of two solutions with incorporation of PCM in gypsum plasterboard. In one side the plasterboard used had $12 \mathrm{~mm}$ of thickness, all impregnated with PCM in order to compare with another situation in which they applied single plasterboards with $10 \mathrm{~mm}$ of thickness, covered by PCM laminate with $2 \mathrm{~mm}$. The amount of PCM incorporated in both cases was the same. The results showed that the use of PCM laminate is more efficient since it contributed to an increase in the minimum temperature. However, other solutions had also been developed like alveolar PVC panels with PCM macroencapsulated, blocks, bricks and mortars [6,13,14]. Cabeza et al. [6], constructed and monitored the behavior of concrete test cells, with and without addition of $5 \%$ of PCM microcapsules. The incorporation of PCM was made in the concrete used on the roof and south and west walls. During the summer and without ventilation a decrease in maximum temperature and a time lag of about $2 \mathrm{~h}$ were recorded. Other studies demonstrated more interest in evaluates the influence of adding PCM in the main properties of the materials. Cunha et al. [14] developed a study incorporating two different PCM in mortars evaluating the influence of these materials in the fresh and hardened state of the mortars. It was verified that the use of PCM microcapsules provides different characteristics in the different mortars, which is related to the type of polymer used in the wall of the microcapsules and also to their size. Other studies had interest in studying some characteristics of materials doped with PCM. The incorporation of PCM in concrete has shown some promising results through lower thermal conductivity and an increase in thermal mass at specific temperatures. However, the concrete with incorporation of PCM has shown some undesirable properties such as lower strength, uncertain long-term stability and lower fire resistance [15].

The safety requirements for materials used in buildings is a crucial point for the PCM, it should not be toxic or flammable [1]. Bearing this in mind it is important to understand the behavior of the materials in aggressive conditions. The exposure of the construction materials at high temperatures has a huge influence in their properties, since when subjected to this action they can present a very distinct behavior compared with the normal conditions. The materials used in buildings can significantly affect the characteristics of a developing fire. Thus, the investigation of the behavior of construction materials in high temperatures is essential, due to their potential impact on the overall fire safety of a building [3].

The scientific community had conducted studies in the framework of the reaction to fire and high temperature behavior. However, the study of the behavior at high temperatures of mortars incorporating phase change materials (PCM) is one of the main knowledge gaps. The commercially available organic PCM are mainly paraffin blends since they exhibit a range of desirable characteristics, such as high latent heat, ability to control the phase change temperature, low cost, non-corrosive characteristics and chemical stability. However, these materials exhibit two main weaknesses, the low thermal conductivity and increased flammability which can compromise the fire safety characteristics of a building [3]. Thus, the main objective of this work was the effect of the high temperatures on mortars with incorporation of PCM, based on different binders. The binders studied were aerial lime, hydraulic lime, gypsum and cement. The use of lime based mortars are especially important in building retrofitting in which render compatibility must be assured [16]. The proportion of PCM studied was $0 \%$ and $40 \%$ of the sand mass. Tests were performed with 12 different compositions at 3 different temperature ranges, evaluating the flexural, compression and adhesion strengths.

\section{Experimental program}

\subsection{Materials}

The selection of the materials took in account previous works [14,17-19]. The influence of adding PCM in mortars for interior coating was studied. Mortars were based on the following binders: aerial lime, hydraulic lime, gypsum and cement The aerial lime used has a purity of $90 \%$ and density of $2450 \mathrm{~kg} / \mathrm{m}^{3}$. The gypsum used is a traditional one, with high fineness and density of $2740 \mathrm{~kg} / \mathrm{m}^{3}$. The hydraulic lime was a natural lime (NHL5) with density of $2550 \mathrm{~kg} / \mathrm{m}^{3}$. The cement used was a CEM II B-L $32.5 \mathrm{~N}$ with density of $3030 \mathrm{~kg} / \mathrm{m}^{3}$.

The PCM used is composed of a wall in melamine-formaldehyde and a core in paraffin with transition temperature of about $22.5^{\circ} \mathrm{C}$, enthalpy of $147.9 \mathrm{~kJ} / \mathrm{kg}$ and density of $880 \mathrm{~kg} / \mathrm{m}^{3}$ (Fig. 1). The process of fabrication is polycondensation by addition and the material is commercialized by the Devan Chemicals, with the commercial name of Mikathermic D24. This PCM exhibits a transition temperature of $24^{\circ} \mathrm{C}$ in the heating cycle and $21^{\circ} \mathrm{C}$ in the cooling cycle. Granulometry tests were performed, using a laser particle size analyser, in order to determine the dimensions of PCM microcapsules. It was possible to observe a particle size distribution between 5.8 and $339 \mu \mathrm{m}$, with $80 \%$ of particle size between 10.4 and $55.2 \mu \mathrm{m}$ (Fig. 2). The average particle size is $43.91 \mu \mathrm{m}$.

The superplasticizer used was a polyacrylate, with a density of $1050 \mathrm{~kg} / \mathrm{m}^{3}$. The sand used has an average particle size of $439.9 \mu \mathrm{m}$ and a density of $2600 \mathrm{~kg} / \mathrm{m}^{3}$. Finally, the fibers used are synthetic fibers of polyamide, with a length of $6 \mathrm{~mm}$, $22.3 \mu \mathrm{m}$ of thickness (Fig. 3) and density of $1380 \mathrm{~kg} / \mathrm{m}^{3}$.

\subsection{Compositions}

In order to develop this study an experimental campaign was considered. Twelve compositions were studied with the main goal of characterizing the effect of high temperatures, based in the mechanical properties changes.

The studied compositions are presented in Table 1. The used compositions have different contents of PCM ( $0 \%$ and $40 \%$ ) and different binders (aerial lime, hydraulic lime, gypsum and cement). In order to overcome some of the problems related with the low flexural and compressive strengths verified in the aerial lime based mortars with incorporation of microcapsules of PCM, it was decided to incorporate a higher content of binder.

\subsection{Mechanical characterization}

The mixture procedure and specimens preparation for the compression and flexural tests followed the standard EN 1015-11 [20]. For each composition and exposure temperature, 3 prismatic specimens with $40 \times 40 \times 160 \mathrm{~mm}^{3}$ were prepared. Regarding the adhesion tests, the mixture procedure and specimens preparation followed the standard EN 1015-12 [21]. For each studied composition and exposure temperature, 5 circular test areas with a diameter of $50 \mathrm{~mm}$ were prepared. After their preparation all the specimens were stored during 7 days in polyethylene bags and subsequently placed in the laboratory at regular room temperature (about $22^{\circ} \mathrm{C}$ ) during 21 days.

The flexural and compression behavior was determined based in the standard EN 1015-11 [20]. The flexural tests were performed with load control at a speed of $50 \mathrm{~N} / \mathrm{s}$. Compressive tests were realized through the application of a load on the specimen with resource to a metallic piece, rigid enough to make the vertical load uniform. The specimens used for the test were the half parts resulting from the flexural test. The compressive tests were performed with a load control at a speed of $150 \mathrm{~N} / \mathrm{s}$.

The adhesion tests were performed based on the standard EN 1015-12 [21]. It was possible to estimate the adhesion of the mortars at 28 days, when applied to a ceramic substrate frequently used in the construction industry to perform masonry. The tests were performed only for the reference compositions ( $0 \% \mathrm{PCM}$ ) and those with incorporation of $40 \%$ of PCM and $1 \%$ of polyamide fibers, since the 


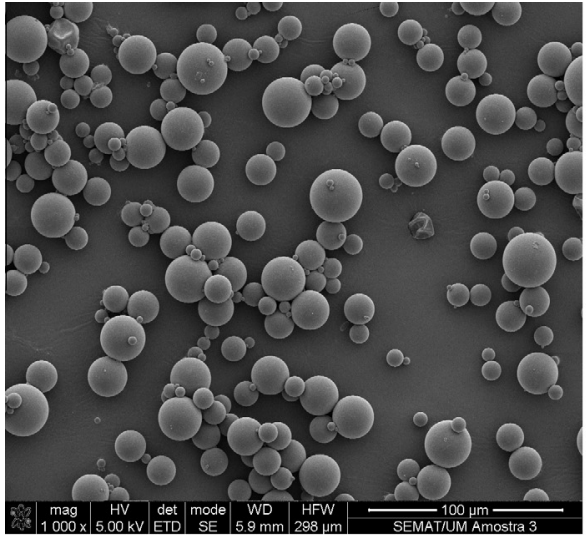

(a)

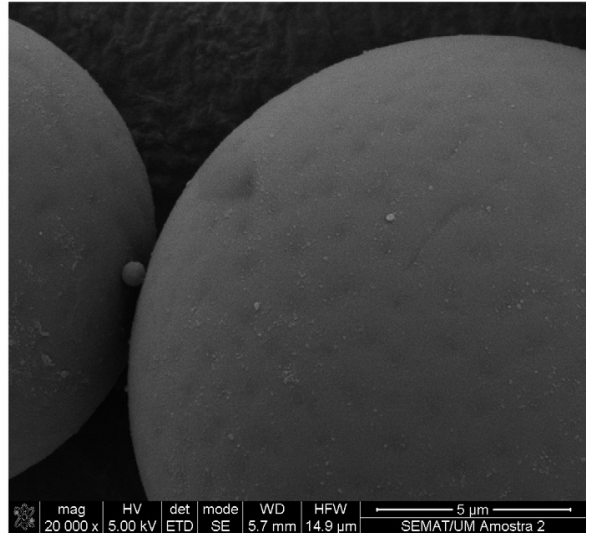

(b)

Fig. 1. Microscope observation of polymer surface of the microcapsules: a) enlargement of 1000x; b) enlargement of 20000x.

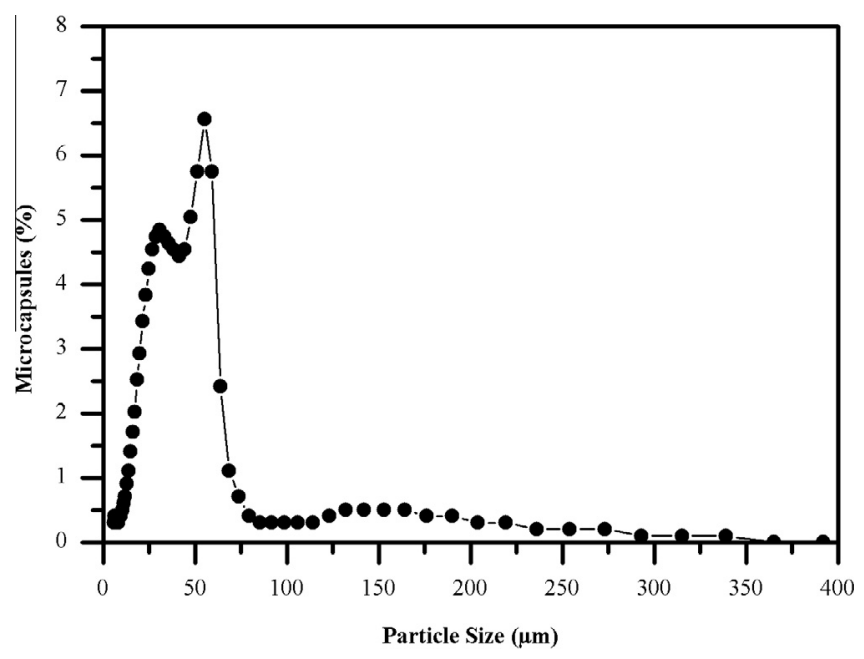

Fig. 2. Particle size distribution of PCM microcapsules.

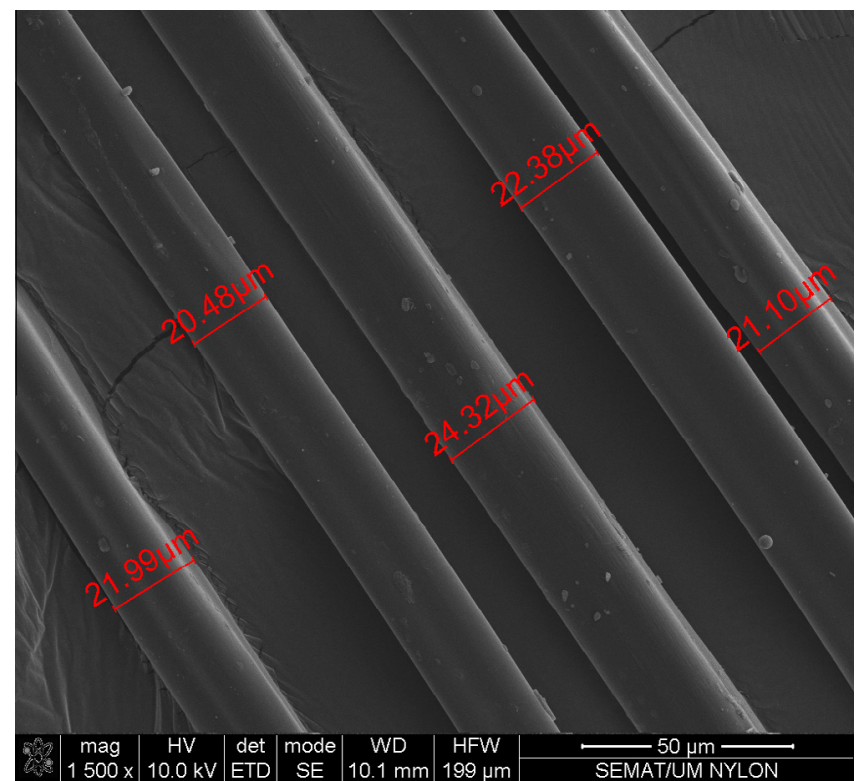

Fig. 3. Microscope observation of polyamide fibers, enlargement of 1500x. compositions with incorporation of $40 \%$ of PCM and without addition of fibers showed cracks in surface caused by shrinkage, making impossible to perform these tests.

\section{Test results and discussion}

\subsection{Workability}

The workability tests were performed with the main goal of verifying the adequacy of application of the developed mortars. The tests were performed based on the flow table method stated by the European standard EN 1015-3 [22]. The resulting value within the test was only considered when equal to $205 \pm 5 \mathrm{~mm}$.

According to Fig. 4 it was observed changes in the amount of water added to the mortars with the incorporation of PCM microcapsules. It was possible to verify an increase in water content with the incorporation of PCM microcapsules. The incorporation of $40 \%$ of PCM microcapsules causes an increase in the amount of water superior to $15 \%$, with exception of cement based mortars. This increase in water content can be explained by the reduced particle dimension of the used PCM. The incorporation of fibers did not cause significant changes in the water content of to the mortars.

\subsection{Density}

Regarding the density of the different mortars it was observed a decrease of its value with the incorporation of PCM microcapsules (Fig. 5). The incorporation of $40 \%$ of PCM caused a decrease in the mortars density of about $30 \%$ for all tested binders. This behavior can be explained by the low density of the PCM microcapsules and the increase in the water quantity used to produce these mortars. The incorporation of fibers did not cause changes in the density because the content used in each composition was low.

\subsection{Mechanical performance}

Different tests were performed, in order to evaluate the effect of high temperatures on mortars with addition of PCM. Flexural, compressive and adhesion tests were performed. The tests were performed submitting the specimens to high temperatures during $4 \mathrm{~h}$, with resource to an oven. Each composition was tested at three different temperatures ranges. The used temperatures were $20^{\circ} \mathrm{C}$ (reference temperature), $200{ }^{\circ} \mathrm{C}$ and $600^{\circ} \mathrm{C}$. The exposure to high temperatures occurred after curing the specimens for 28 days. 
Table 1

Mortars formulation $\left(\mathrm{kg} / \mathrm{m}^{3}\right)$

\begin{tabular}{|c|c|c|c|c|c|c|c|}
\hline Composition & Binder & & Sand & PCM & SP & Fibers & Water/Binder \\
\hline СА500-0РCM & Aerial lime & 500 & 1447.2 & 0 & 15 & 0 & 0.45 \\
\hline СА800-40РСМ & Aerial lime & 800 & 451.2 & 180.5 & 24 & 0 & 0.34 \\
\hline CA800-40PCM-F & Aerial lime & 800 & 425.2 & 170.1 & 24 & 8 & 0.36 \\
\hline CH500-0PCM & Hydraulic lime & 500 & 1351.1 & 0 & 15 & 0 & 0.54 \\
\hline CH500-40PCM & Hydraulic lime & 500 & 571.6 & 228.6 & 15 & 0 & 0.62 \\
\hline CH500-40PCM-F & Hydraulic lime & 500 & 567.2 & 226.9 & 15 & 5 & 0.62 \\
\hline C32.5N500-0PCM & CEM II B-L 32.5N & 500 & 1418.8 & 0 & 15 & 0 & 0.55 \\
\hline C32.5N500-40PCM & CEM II B-L 32.5N & 500 & 644.3 & 257.7 & 15 & 0 & 0.56 \\
\hline C32.5N500-40PCM-F & CEM II B-L $32.5 \mathrm{~N}$ & 500 & 622.2 & 248.8 & 15 & 5 & 0.59 \\
\hline G500-0PCM & Gypsum & 500 & 1360.4 & 0 & 15 & 0 & 0.56 \\
\hline G500-40PCM & Gypsum & 500 & 540.1 & 216.0 & 15 & 0 & 0.70 \\
\hline G500-40PCM-F & Gypsum & 500 & 535.8 & 214.3 & 15 & 5 & 0.70 \\
\hline
\end{tabular}

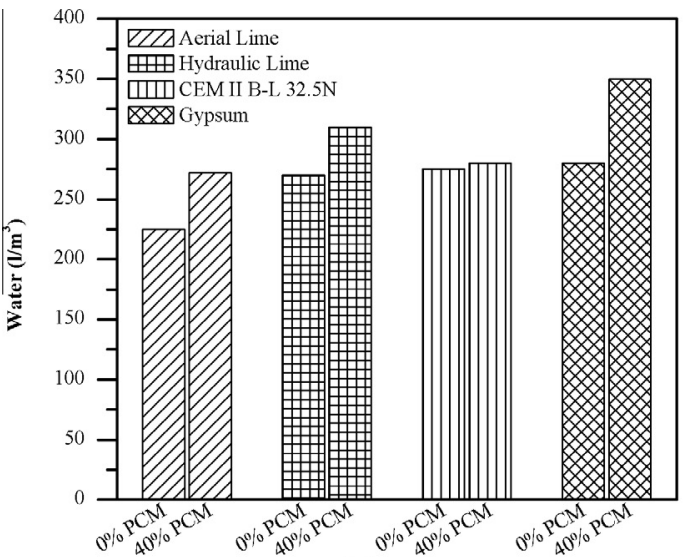

(a)

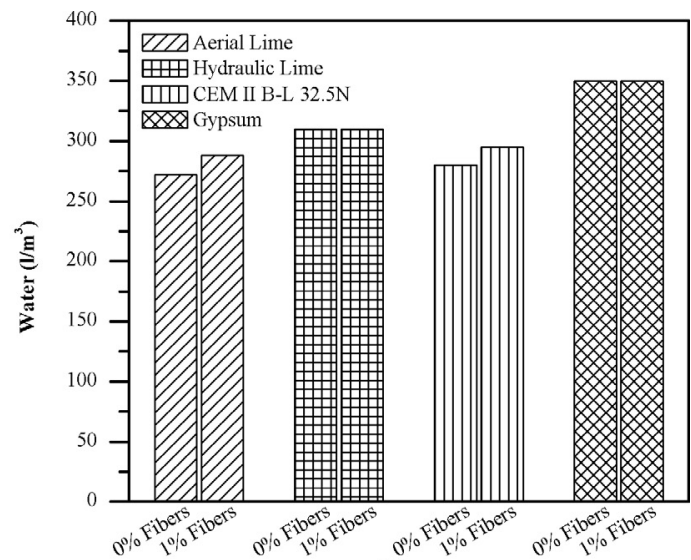

(b)

Fig. 4. Water content of mortars: a) Variation with PCM content, b) Variation with fibers content.

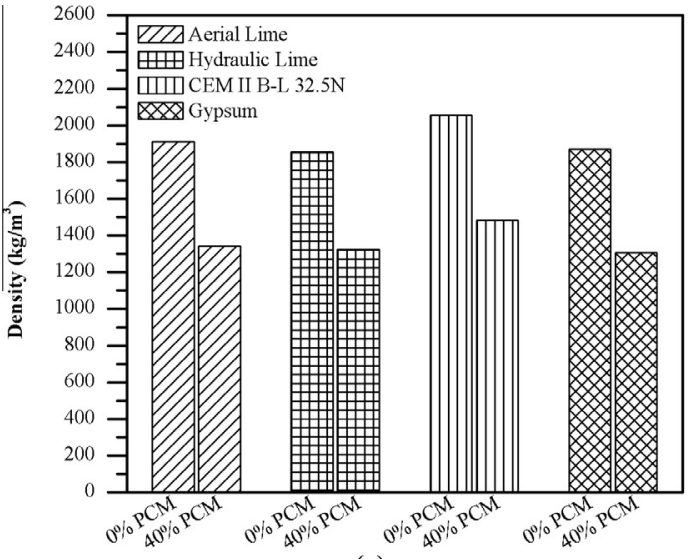

(a)

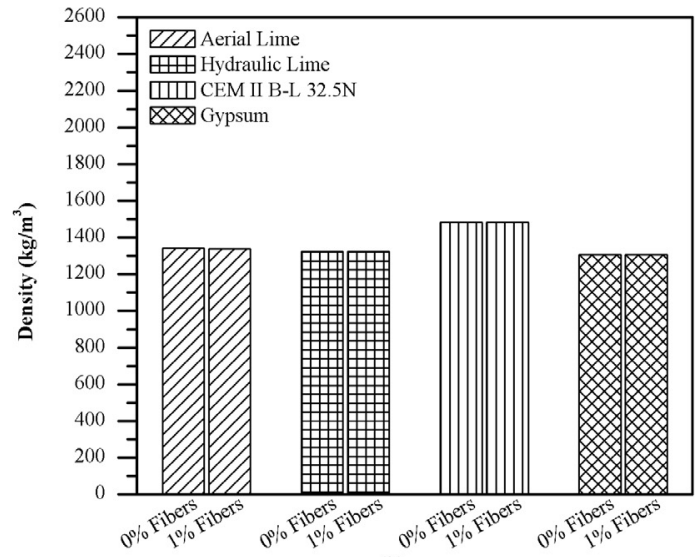

(b)

Fig. 5. Density of mortars: a) Variation with PCM content, b) Variation with fibers content.

\subsubsection{Flexural behavior}

According to the results (Fig. 6) it was verified a decrease in the flexural strength caused by the exposure to high temperatures.

Regarding the reference mortars ( $0 \%$ PCM), it was observed that for a temperature of $200{ }^{\circ} \mathrm{C}$ these did not exhibit a considerable decrease in the flexural strength with exception of the gypsum based mortars. However, for the exposure temperature of $600{ }^{\circ} \mathrm{C}$ it was possible to observe that the loss suffered in the flexural strength was more significant. The decrease in the flexural strength of gypsum based mortars is related to the chemical change that occurs when the gypsum is exposed to temperatures higher than $100{ }^{\circ} \mathrm{C}$ [23]. The exposure of reference mortars to a temperature of $600{ }^{\circ} \mathrm{C}$ leads to a decrease in the flexural strength superior to 75\%. This behavior can be explained by the expansion and development of micro cracks in the mortar when subjected to high temperatures [24]. These micro cracks can also be caused by the internal high-pressure steam generated in the specimens when subjected to high temperatures and by the presence of a thermal gradient between the outer and inner layers of the specimens [25]. The presence of micro cracks reduces the resistant cross 

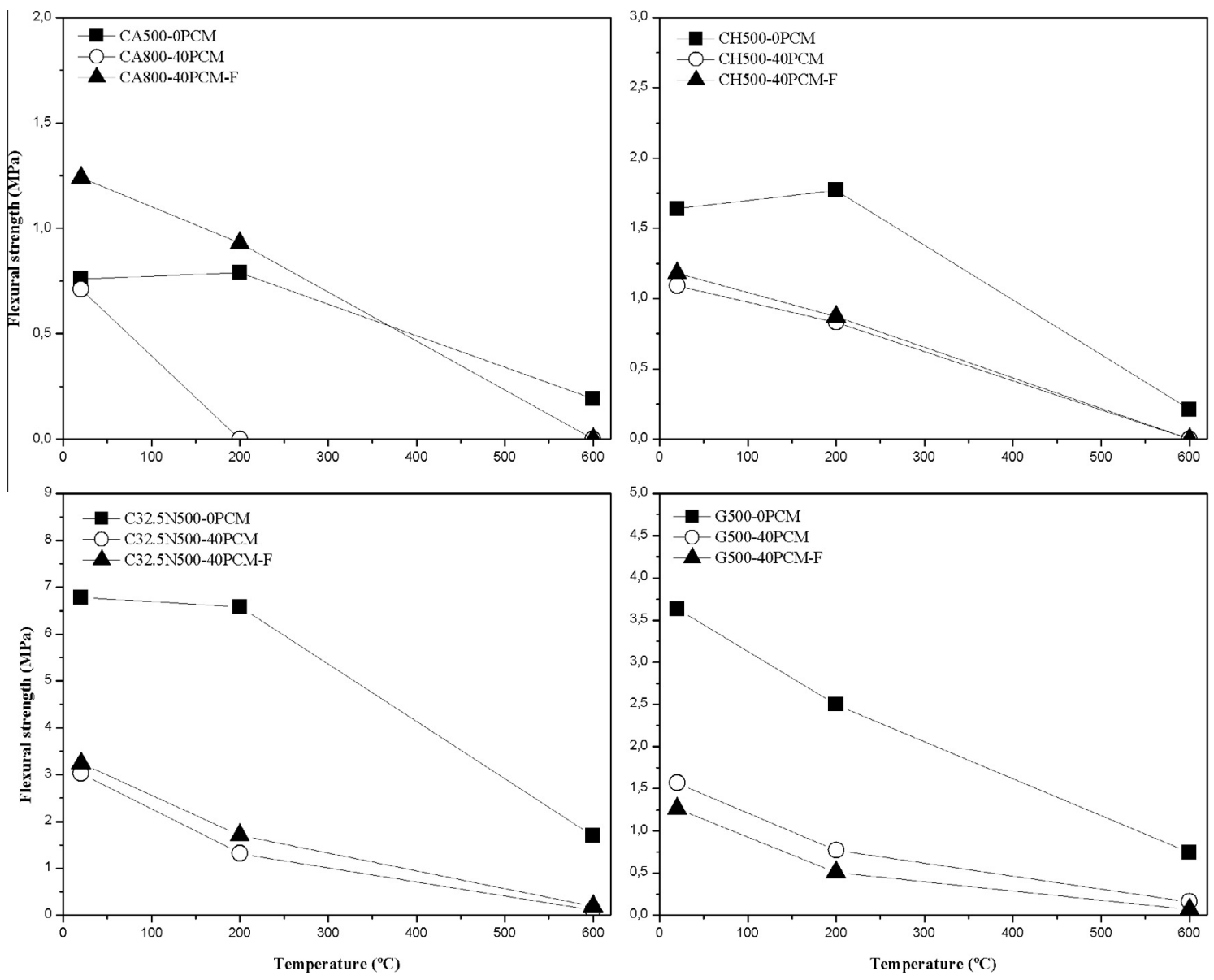

Fig. 6. Flexural behavior of mortars after exposure to high temperatures.

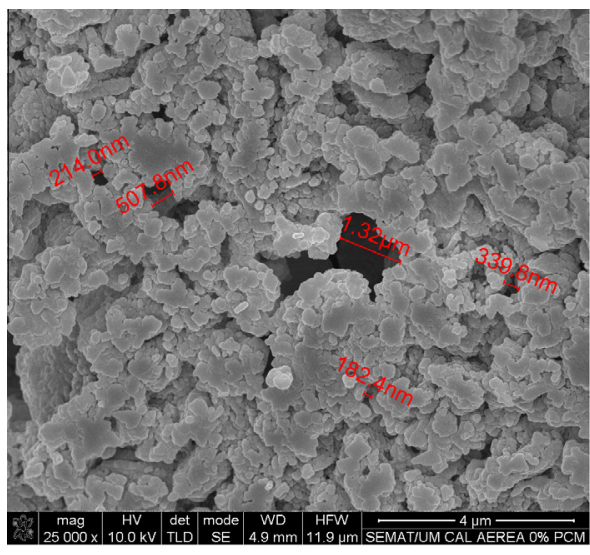

(a)

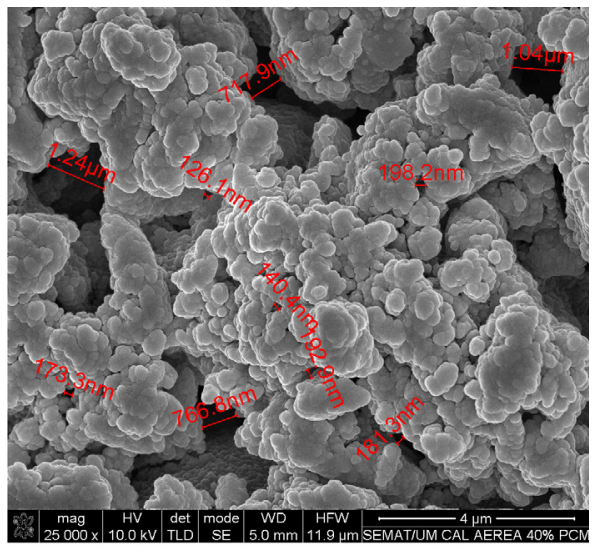

(b)

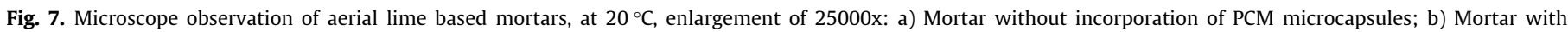
incorporation of $40 \%$ of PCM microcapsules.

section area, decreasing the flexural strength of the mortars [26]. The decrease in the flexural strength verified in the exposure temperature of $600^{\circ} \mathrm{C}$, can also be justified by the decomposition of calcium hydroxide present in the binders, that occurs at $450-550{ }^{\circ} \mathrm{C}[27]$.

For the mortars with incorporation of microcapsules of PCM it was observed for all tested temperatures a flexural strength lower than in the reference mortars ( $0 \%$ PCM). This decrease can be explained by the increased amount of water added to the compositions with incorporation of PCM. Note that the increase of water content in the mortars with the addition of PCM causes an increase in the microporosity which leads to a decrease in their mechanical strength (Figs. 7-10). Regarding to an exposure to a temperature of $200{ }^{\circ} \mathrm{C}$, it was verified a decrease in the flexural strength higher than $25 \%$. The submission of the specimens to a temperature of $600{ }^{\circ} \mathrm{C}$ leads to a decrease of the flexural strength higher than $90 \%$. In some cases, the total destruction of the specimens has been verified, and therefore its resistance was considered null (Fig. 11). With the temperature increase the cracking phenomena occur as described for the reference mortars, however in this case the 


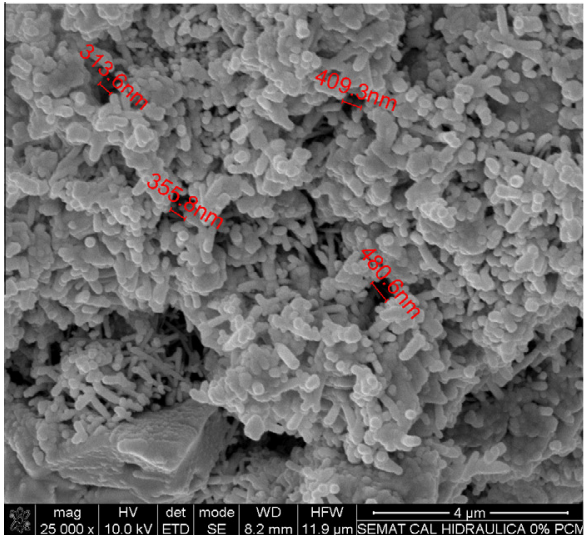

(a)

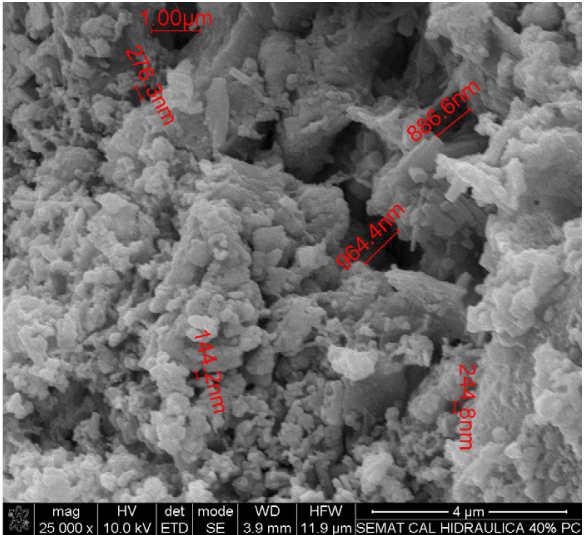

(b)

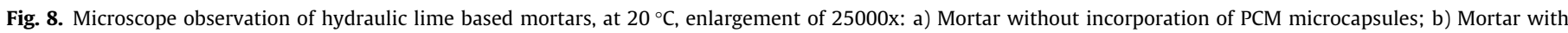
incorporation of $40 \%$ of PCM microcapsules.

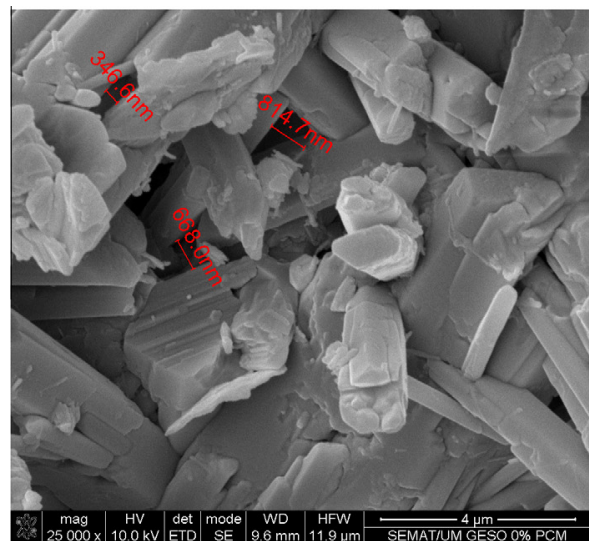

(a)

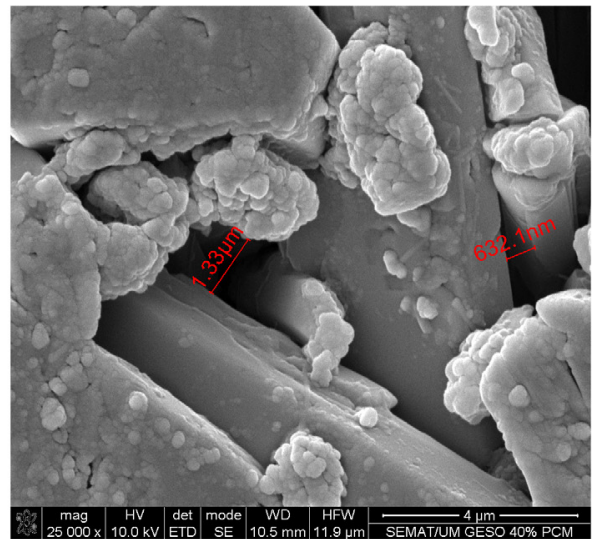

(b)

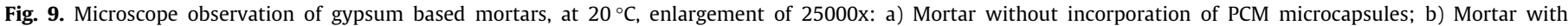
incorporation of $40 \%$ of PCM microcapsules.

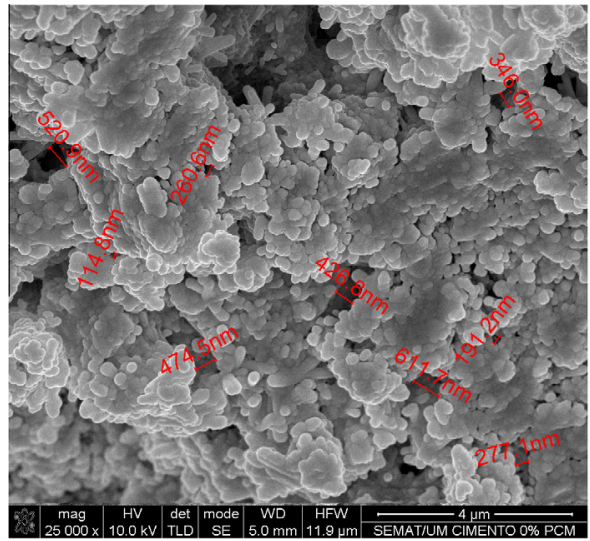

(a)

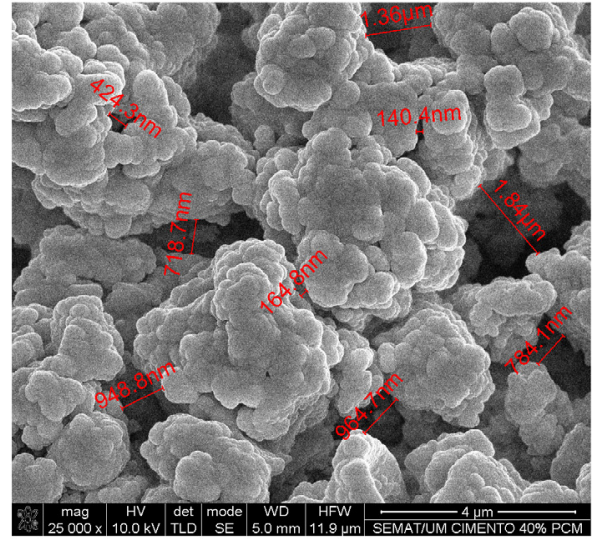

(b)

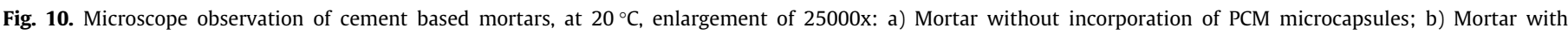
incorporation of $40 \%$ of PCM microcapsules.

expansion coefficient of the material of the PCM microcapsule (polymeric) is higher than the expansion coefficient of the binder paste, increasing the stresses generated in the specimens [24].

According Figs. 7-10 it was also possible observe a good connection between the different materials constituents of the mortars and a homogeneous distribution in their matrix. The PCM showed a good integrity, without signs of rupture or damages, which demonstrates that the microcapsules can resist adequately to the process of mortar mixing, application and curing.

The addition of fibers in mortars with incorporation of microcapsules of PCM provides different effects in flexural strength taking into account the binder used. Thus, the mortars based on aerial 


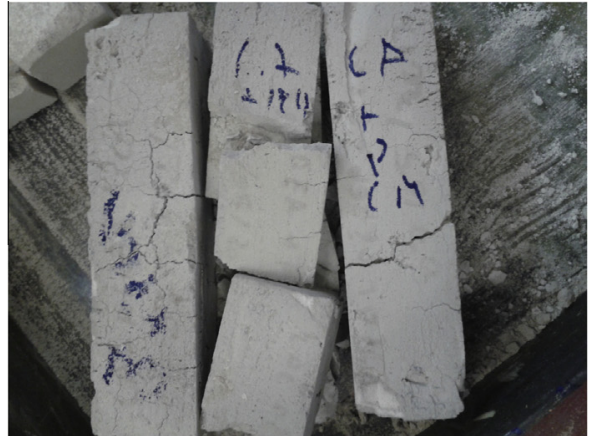

(a)

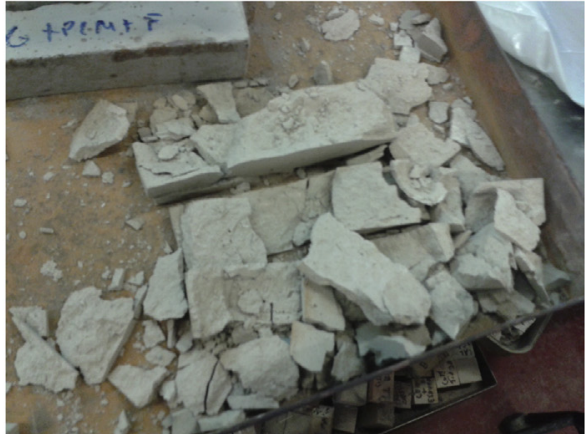

(b)

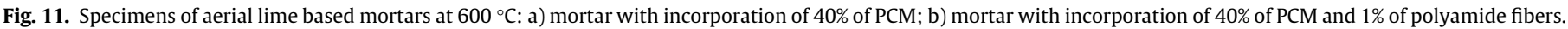

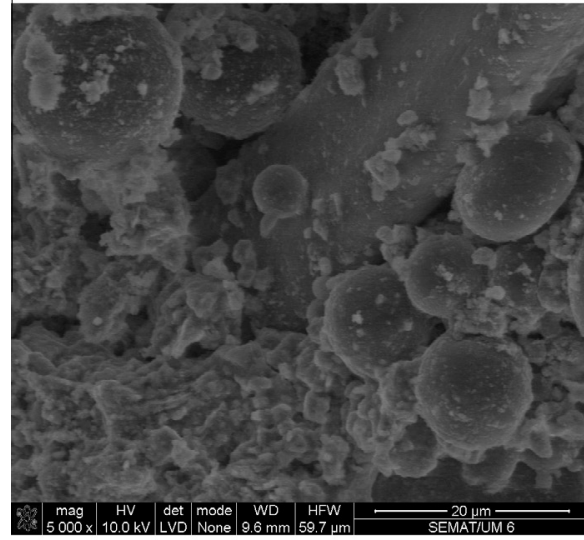

(a)

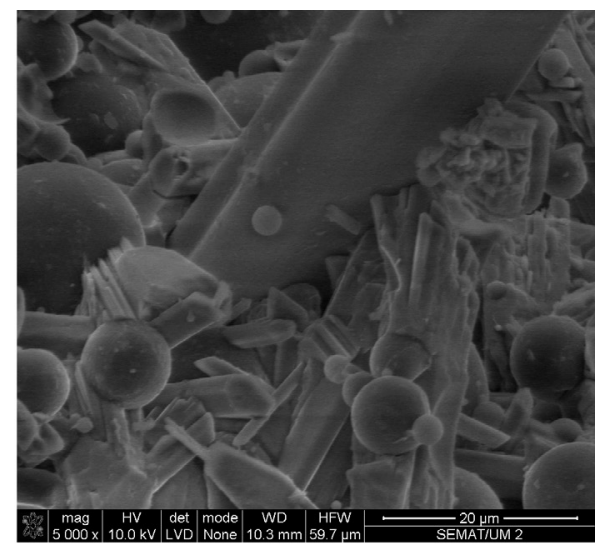

(b)

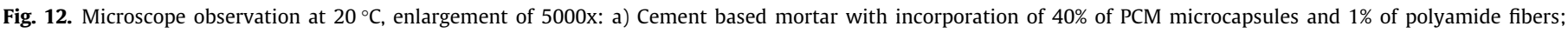
b) Gypsum based mortar with incorporation of $40 \%$ of PCM microcapsules and $1 \%$ of polyamide fibers.

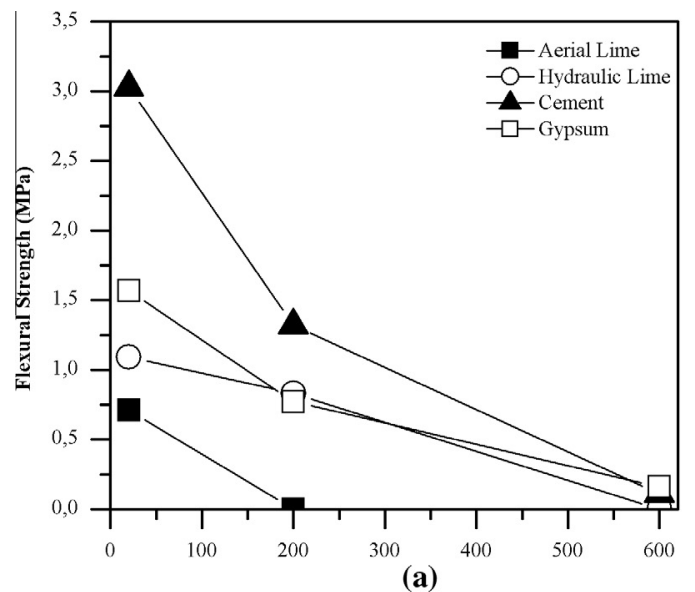

Temperature $\left({ }^{\circ} \mathrm{C}\right)$

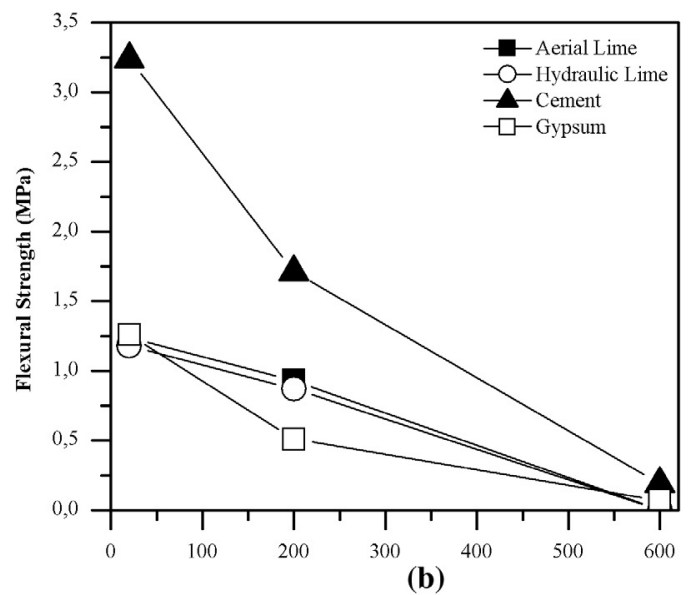

Temperature $\left({ }^{\circ} \mathrm{C}\right)$

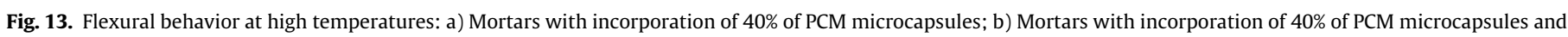
$1 \%$ of polyamide fibers.

lime, hydraulic lime and cement present an increase in the flexural strength compared with the mortars without addition of fibers, for all tested temperatures. In contrast, for the gypsum based mortars the incorporation of fibers has a negative effect, showing a flexural strength lower than the mortars with PCM. This behavior can be justified by the lower adhesion of the fibers to the matrix of gypsum mortars when compared to the other binders (Fig. 12). It was observed a decrease of the hydration products present in the connection between the matrix and the fibers.

It was found that the temperature increase leads to a decrease in flexural strength of mortars incorporating PCM and fibers, this situation can be explained by the presence of higher water content and the higher expansion coefficients of the fibers (polymeric) compared with the binder paste and sand expansion coefficients. 
Table 2

Variation of flexural strength at $200{ }^{\circ} \mathrm{C}$ and $600{ }^{\circ} \mathrm{C}$ compared with the flexural strength at $20^{\circ} \mathrm{C}$.

\begin{tabular}{|c|c|c|c|}
\hline Composition & Binder & Variation of flexural strength at $200{ }^{\circ} \mathrm{C}(\%)$ & Variation of flexural strength at $600{ }^{\circ} \mathrm{C}(\%)$ \\
\hline CA500-0PCM & Aerial lime & 4 & -75 \\
\hline CA800-40PCM & Aerial lime & -100 & -100 \\
\hline CA800-40PCM-F & Aerial lime & -25 & -100 \\
\hline CH500-0PCM & Hydraulic lime & 8 & -87 \\
\hline CH500-40PCM & Hydraulic lime & -24 & -100 \\
\hline CH500-40PCM-F & Hydraulic lime & -26 & -100 \\
\hline C32.5N500-0PCM & CEM II B-L 32.5N & -3 & -75 \\
\hline C32.5N500-40PCM & CEM II B-L $32.5 \mathrm{~N}$ & -56 & -96 \\
\hline C32.5N500-40PCM-F & CEM II B-L 32.5N & -47 & -94 \\
\hline G500-0PCM & Gypsum & -31 & -80 \\
\hline G500-40PCM & Gypsum & -51 & -90 \\
\hline G500-40PCM-F & Gypsum & -60 & -94 \\
\hline
\end{tabular}
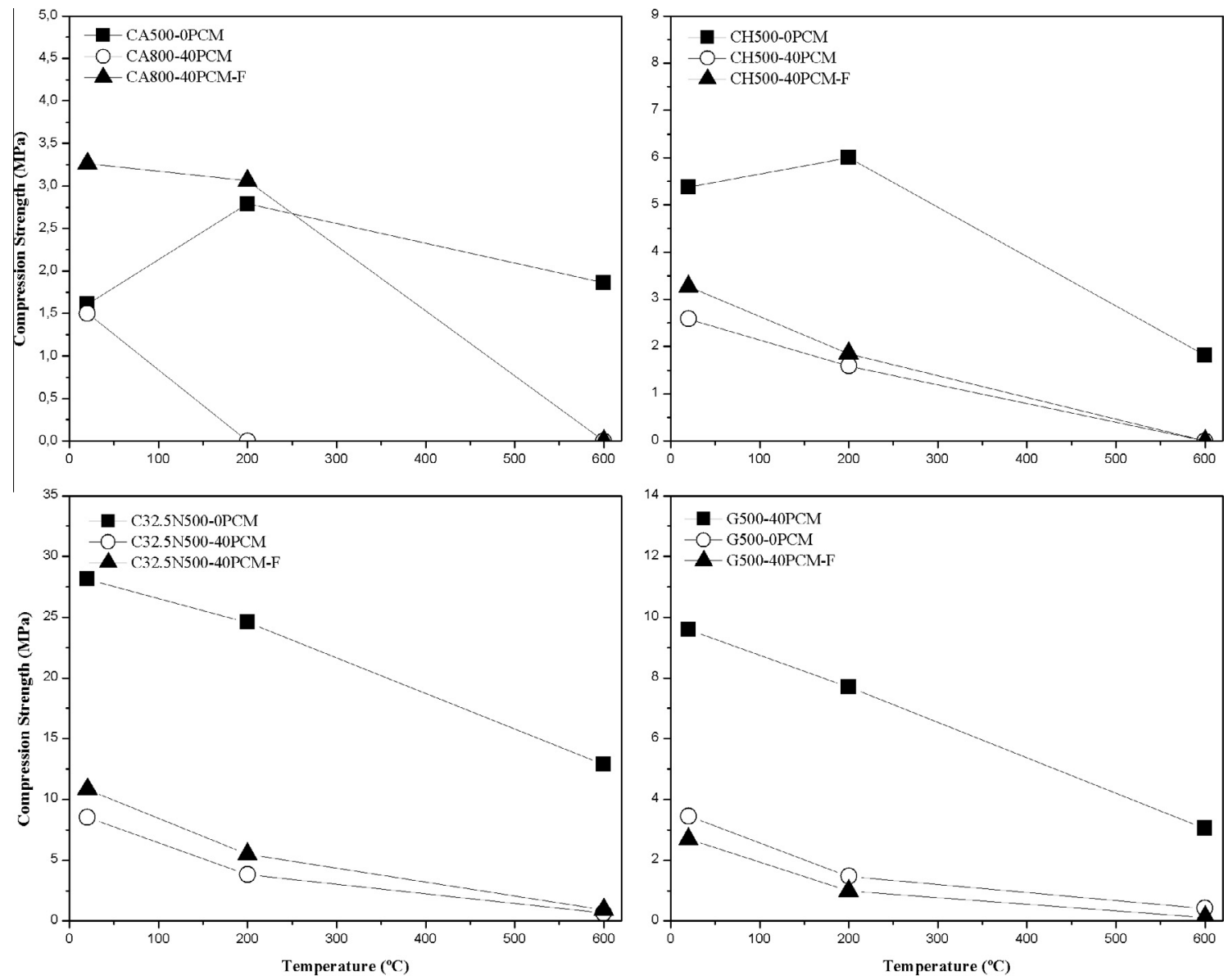

Fig. 14. Compression behavior at high temperatures.

Fig. 13 and Table 2 show the influence of the temperature in flexural strength of the different mortars. Thus, it was verified that the most sensitive binder to high temperature is the aerial lime, because there was a total destruction of the specimens for $200^{\circ} \mathrm{C}$. The binder that showed a better behavior, regarding the lower resistance losses for an exposure of $200^{\circ} \mathrm{C}$ was the hydraulic lime. The binder that presents higher flexural strength for the exposure temperature of $600{ }^{\circ} \mathrm{C}$ was the cement. However, it was possible observe that the cement based mortars presented a decrease similar to the other binders. The high value of flexural strength can be explained by the nature of the different used binders. It is known that cement based mortars usually present higher mechanical strength when compared to the other binders. In addition, the components resulting from the cement hydration are more resistant to high temperatures than the corresponding components of other binders.

\subsubsection{Compression behavior}

According to Fig. 14 and Table 3, it is possible to verify a decrease in the compression strength caused by the exposure to high temperatures, for the majority of the studied mortars.

The reference mortars based on aerial lime and hydraulic lime when exposed to a temperature of $200{ }^{\circ} \mathrm{C}$ showed an improvement in its compressive strength higher than $12 \%$, however for a 
Table 3

Variation of compressive strength at $200{ }^{\circ} \mathrm{C}$ and $600{ }^{\circ} \mathrm{C}$ compared with the compressive strength at $20^{\circ} \mathrm{C}$.

\begin{tabular}{|c|c|c|c|}
\hline Composition & Binder & Variation of compressive strength at $200{ }^{\circ} \mathrm{C}(\%)$ & Variation of compressive strength at $600{ }^{\circ} \mathrm{C}(\%)$ \\
\hline CA500-0PCM & Aerial lime & 73 & 16 \\
\hline CA800-40РCM & Aerial lime & -100 & -100 \\
\hline CA800-40PCM-F & Aerial lime & -7 & -100 \\
\hline CH500-0PCM & Hydraulic lime & 12 & -66 \\
\hline CH500-40PCM & Hydraulic lime & -38 & -100 \\
\hline CH500-40PCM-F & Hydraulic lime & -43 & -100 \\
\hline C32.5N500-0PCM & CEM II B-L 32.5N & -13 & -54 \\
\hline C32.5N500-40PCM & CEM II B-L $32.5 \mathrm{~N}$ & -55 & -92 \\
\hline C32.5N500-40PCM-F & CEM II B-L 32.5N & -49 & -92 \\
\hline G500-0PCM & Gypsum & -20 & -68 \\
\hline G500-40PCM & Gypsum & -57 & -88 \\
\hline G500-40PCM-F & Gypsum & -64 & -96 \\
\hline
\end{tabular}
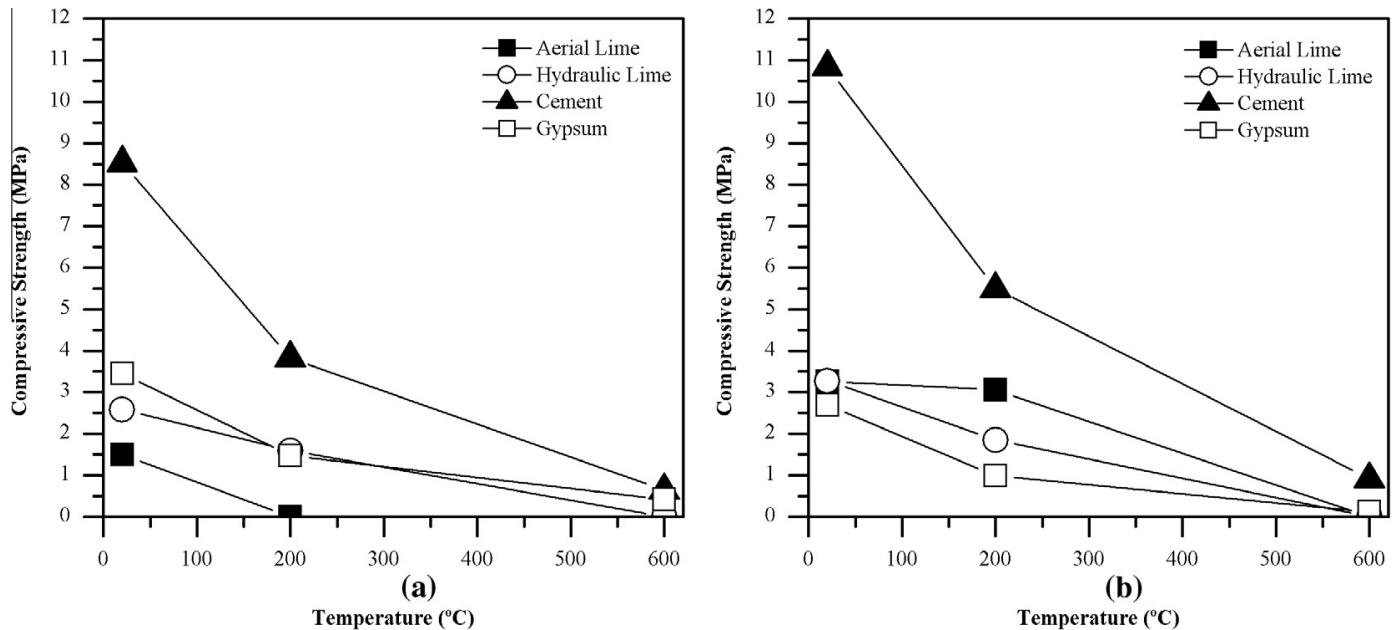

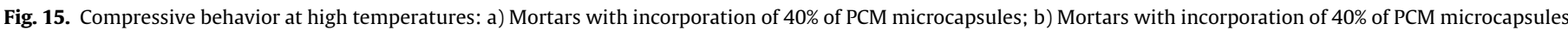
and $1 \%$ of polyamide fibers.

temperature of $600{ }^{\circ} \mathrm{C}$ the compressive strength decreases. To understand the increase observed for a temperature range of $200{ }^{\circ} \mathrm{C}$, it is important to realize the curing process of these types of binders [26]. The curing process of aerial lime based mortars occurs in two distinct stages. First, it occur the evaporation of water and consequently a contraction of the volume of mortar. In the second stage, there is a slow reaction of carbon dioxide with aerial lime, appearing the calcium carbonate that will increase the mechanical strength of the mortar. In mortars based on hydraulic lime the curing process takes place in two stages. First, hydraulic lime has a rapid hydration reaction of its hydraulic compounds with water. In a second stage the mortars suffers carbonation. The carbonation reaction is slow as in the case of mortars based on aerial lime. Thus, the increased temperature accelerates the curing process, which allows for a temperature of $200{ }^{\circ} \mathrm{C}$ higher compressive strength. At temperature of $600^{\circ} \mathrm{C}$ the compressive strength decreases, this situation can be explained by the expansion and appearance of micro cracks caused by the high temperatures. Also, at temperatures between $450{ }^{\circ} \mathrm{C}$ and $550{ }^{\circ} \mathrm{C}$ there is the decomposition of the calcium hydroxide [27].

Reference mortars based on gypsum and cement present a decrease in the compressive strength for a temperature of $200{ }^{\circ} \mathrm{C}$, superior to $13 \%$. This is related to the expansion process connected with the lower porosity of these mortars. The microstructural changes in cement mortars occur due to the loss of water caused by the increase in the temperature that causes the appearance of microcracks [24-26]. Note that, for temperatures between 200 and $600{ }^{\circ} \mathrm{C}$ it is possible that occurs the dehydration processes of the hydrated components of the mortars, increasing the loss of strength [24].

In the mortars with incorporation of $40 \%$ of PCM microcapsules it was verified that for a temperature of $20^{\circ} \mathrm{C}$ (reference temperature) the compressive strength is lower than the reference mortar. It was observed that the incorporation of $40 \%$ of PCM leads a decrease in the compressive strength superior to $52 \%$, for a reference temperature exposure. It was also verified that the compression strength decreases with increasing temperature. The exposure to the specimens at $200{ }^{\circ} \mathrm{C}$ caused a decrease in the compressive strength higher than $39 \%$ when compared to the reference temperature. For a temperature range of $600{ }^{\circ} \mathrm{C}$, it was also verified a decrease in the compressive strength higher than $88 \%$. In some binders, it was observed the total destruction of the specimens. This situation can be justified again by the increase in the amount of water added to the mortar, which causes an increase in their microporosity originating a decrease in its strength. The higher expansion coefficients of the polymeric materials (PCM and fibers) can explain the higher strength decrease verified when these materials are presented into the mortars.

The addition of $1 \%$ of polyamide fibers in mortars with incorporation of PCM microcapsules provides a positive effect in the compressive strength, except for gypsum mortars. Once again, this behavior can be justified by the lower adhesion of the fibers to the matrix of gypsum mortars when compared with the other binders. It was observed an increase in the compression strength higher than $20 \%$ for all tested temperatures when compared to the mortars with incorporation of PCM and without fibers. This 
Table 4

Classification of aerial lime based mortars according to standard NP EN 998-1:2010.

\begin{tabular}{lrll}
\hline Composition & Temperature $\left({ }^{\circ} \mathrm{C}\right)$ & $\begin{array}{l}\text { Compressive } \\
\text { Strength (MPa) }\end{array}$ & $\begin{array}{l}\text { Classification } \\
\text { NP EN 998-1:2010 }\end{array}$ \\
\hline CA500-0PCM & 20 & 1.61 & CSII \\
CA500-0PCM & 200 & 2.79 & CSII \\
CA500-0PCM & 600 & 1.86 & CSII \\
CA800-40PCM & 20 & 1.50 & CSII \\
CA800-40PCM & 200 & 0.00 & - \\
CA800-40PCM & 600 & 0.00 & - \\
CA800-40PCM-F & 20 & 3.26 & CSII \\
CA800-40PCM-F & 200 & 3.06 & CSII \\
CA800-40PCM-F & 600 & 0.00 & -
\end{tabular}

Table 5

Classification of hydraulic lime based mortars according to standard NP EN 998$1: 2010$.

\begin{tabular}{lrll}
\hline Composition & Temperature $\left({ }^{\circ} \mathrm{C}\right)$ & $\begin{array}{l}\text { Compressive } \\
\text { Strength (MPa) }\end{array}$ & $\begin{array}{l}\text { Classification } \\
\text { NP EN 998-1:2010 }\end{array}$ \\
\hline CH500-0PCM & 20 & 5.37 & CSIII \\
CH500-0PCM & 200 & 6.00 & CSIII \\
CH500-0PCM & 600 & 1.81 & CSII \\
CH500-40PCM & 20 & 2.58 & CSII \\
CH500-40PCM & 200 & 1.59 & CSII \\
CH500-40PCM & 600 & 0.00 & - \\
CH500-40PCM-F & 20 & 3.27 & CSII \\
CH500-40PCM-F & 200 & 1.85 & CSII \\
CH500-40PCM-F & 600 & 0.00 & - \\
\hline
\end{tabular}

Table 6

Classification of cement based mortars according to standard NP EN 998-1:2010.

\begin{tabular}{lcll}
\hline Composition & $\begin{array}{l}\text { Temperature } \\
\left({ }^{\circ} \mathrm{C}\right)\end{array}$ & $\begin{array}{l}\text { Compressive } \\
\text { Strength (MPa) }\end{array}$ & $\begin{array}{l}\text { Classification } \\
\text { NP EN 998-1:2010 }\end{array}$ \\
\hline C32.5N500-0PCM & 20 & 28.14 & CSIV \\
C32.5N500-0PCM & 200 & 24.57 & CSIV \\
C32.5N500-0PCM & 600 & 12.87 & CSIV \\
C32.5N500-40PCM & 20 & 8.53 & CSIV \\
C32.5N500-40PCM & 200 & 3.83 & CSIII \\
C32.5N500-40PCM & 600 & 0.64 & CSI \\
C32.5N500-40PCM-F & 20 & 10.84 & CSIV \\
C32.5N500-40PCM-F & 200 & 5.49 & CSIII \\
C32.5N500-40PCM-F & 600 & 0.91 & CSI \\
\hline
\end{tabular}

situation can be justified by the control capacity of the propagation of cracks in the matrix of the mortar. However, it was verified that the exposure to high temperatures leads to a decrease in the compressive strength. For a temperature of $200^{\circ} \mathrm{C}$ and $600{ }^{\circ} \mathrm{C}$ it was observed a decrease in the compressive strength higher than $10 \%$ and $92 \%$, respectively.

Fig. 15 and Table 3 show the influence of the temperature in the compressive strength of the different mortars.

In order to evaluate the influence of the high temperatures in the compression strength classification, the mortars were classified according to standard NP EN 998-1 [28].

According to Table 4, it was possible to observe that the aerial lime based mortars maintain the same strength class (CSII), except for mortars with PCM.

Regarding to hydraulic lime based mortars (Table 5), it was possible to verify a strength class, CSIII, for reference mortar at $20^{\circ} \mathrm{C}$ and $200{ }^{\circ} \mathrm{C}$. The remaining compositions based on this binder present lower strength class, CSII, or no strength class.

Table 6 shows the classification according to compressive strength for cement based mortars. It was possible to observe that the reference mortars exposed to $20^{\circ} \mathrm{C}, 200^{\circ} \mathrm{C}$ and $600{ }^{\circ} \mathrm{C}$ present
Table 7

Classification of gypsum based mortars according to standard NP EN 998-1:2010

\begin{tabular}{lcll} 
Composition & $\begin{array}{l}\text { Temperature } \\
\left({ }^{\circ} \mathrm{C}\right)\end{array}$ & $\begin{array}{l}\text { Compressive } \\
\text { Strength (MPa) }\end{array}$ & $\begin{array}{l}\text { Classification } \\
\text { NP EN 998-1:2010 }\end{array}$ \\
\hline G500-0PCM & 20 & 9.59 & CSIV \\
G500-0PCM & 200 & 7.70 & CSIV \\
G500-0PCM & 600 & 3.05 & CSII \\
G500-40PCM & 20 & 3.45 & CSII \\
G500-40PCM & 200 & 1.47 & CSI \\
G500-40PCM & 600 & 0.41 & CSI \\
G500-40PCM-F & 20 & 2.70 & CSII \\
G500-40PCM-F & 200 & 0.98 & CSI \\
G500-40PCM-F & 600 & 0.12 & -
\end{tabular}

the maximum classification (CSIV). The mortars with incorporation of PCM and PCM and fibers shows a classification CSIV for a temperature of $20^{\circ} \mathrm{C}$, and a classification of CSIII and CSI for a temperature of $200{ }^{\circ} \mathrm{C}$ and $600{ }^{\circ} \mathrm{C}$, respectively.

The gypsum based mortars (Table 7) are the most affected by the addition of PCM and fibers, since the reference mortar obtains a CSIV classification, for exposure temperature of $20^{\circ} \mathrm{C}$ and $200^{\circ} \mathrm{C}$. The remaining compositions obtained the classifications of CSII and CSI. For the exposure temperature of $600{ }^{\circ} \mathrm{C}$, the classifications decreased with the incorporation of PCM, from CSII (reference mortar) to CSI (mortar with PCM) and no classification (mortar with PCM and fibers).

\subsubsection{Adhesion}

According to Fig. 16 it was possible to observe that all the compositions exhibit the same behavior. However, the obtained values are different for different binders and temperatures. Reference mortars (0\% PCM) showed higher values in the adhesion strength compared with the mortars with addition of $40 \%$ of PCM and $1 \%$ fibers, for temperatures of $20^{\circ} \mathrm{C}$ and $200{ }^{\circ} \mathrm{C}$. It was also observed that the increase in temperature causes a decrease in the adhesion strength. The temperature increase leads to an increase in the expansion of the constituent materials of the systems (substrate and mortar), thereby increasing the stress at the interface substrate/mortar. Also, there is a decomposition of the mortars caused by the expansion of their constituents (binder paste, sand, PCM and fibers) originating cracks. Also, there is the dehydration process of some hydrated components of mortars.

Regarding to the temperature exposure of $20^{\circ} \mathrm{C}$ it was possible to observe that the incorporation of $40 \%$ PCM and $1 \%$ of fibers leads to a decrease in the value of adhesion of about $33 \%$. This behavior can be justified by the increase of the water/binder ratio due to the introduction of a higher content of PCM which caused higher porosity in mortars (Figs. 7-10).

For the temperature of $600{ }^{\circ} \mathrm{C}$ any adhesion strength value could be obtained because exposure of the mortars to this temperature led to a very excessive degradation, making impossible to perform the test (Fig. 17).

Table 8 shows the variation in the adhesion strength of the different mortars submitted to a temperature of $200{ }^{\circ} \mathrm{C}$ and $600{ }^{\circ} \mathrm{C}$. These values were obtained by comparing with the values obtained for the mortars exposed to a temperature of about $20^{\circ} \mathrm{C}$. Thus, it was possible to verify that the binder with better behavior and consequently lower resistance losses was the hydraulic lime.

The aerial lime based mortars present a decrease of adhesion strength when subjected to a temperature of $200{ }^{\circ} \mathrm{C}$ of about $25 \%$ for the reference mortar and a decrease of about $63 \%$ for the mortars with incorporation of $40 \%$ of PCM and $1 \%$ of fibers.

Regarding the hydraulic lime based mortars, it was possible to observe a decrease in the adhesion strength of about $27 \%$ and $33 \%$, for the reference mortars and for the mortars with 

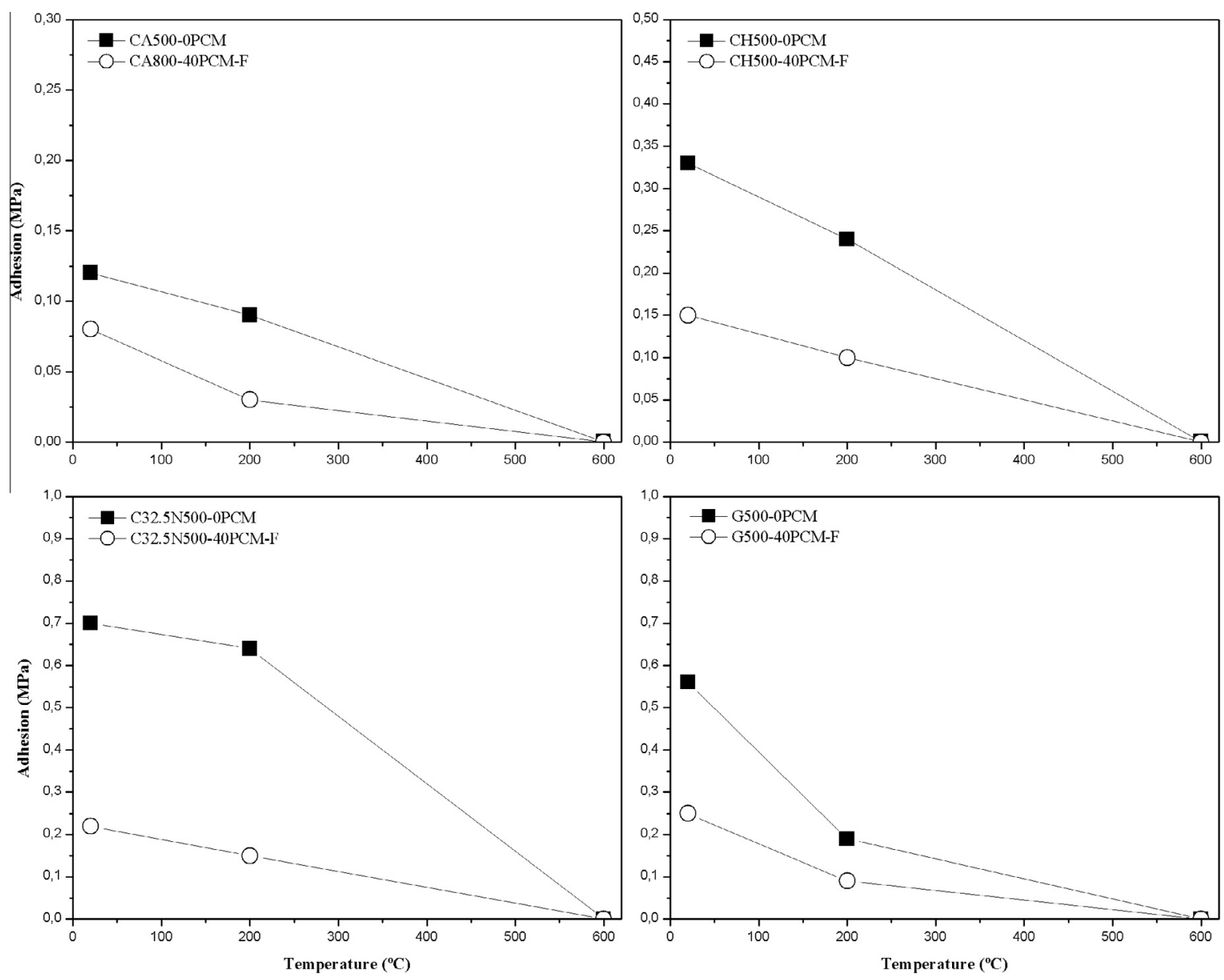

Fig. 16. Influence of temperature in the adhesion.

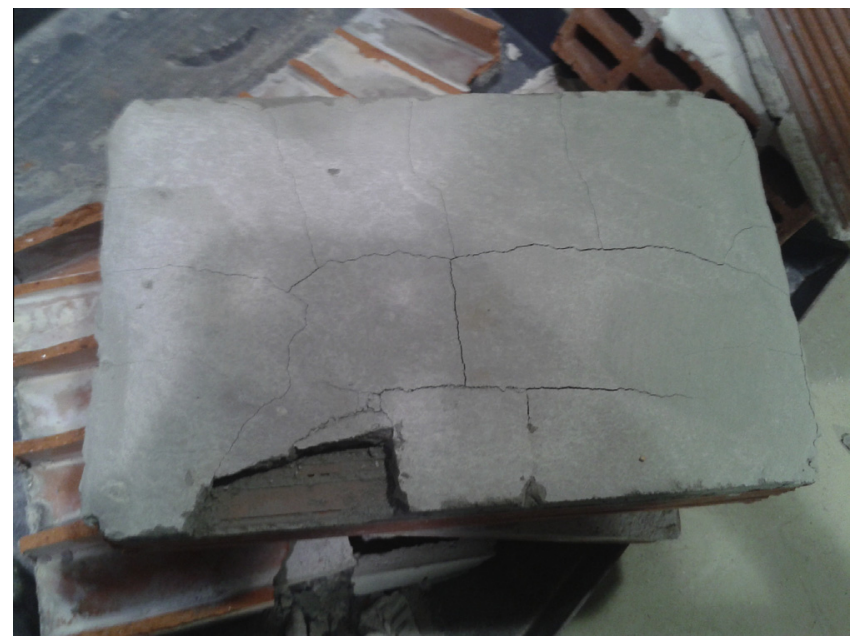

Fig. 17. Specimens of cement based mortar exposure to $600{ }^{\circ} \mathrm{C}$.

incorporation of $40 \%$ of PCM and fibers, respectively, when exposed to a temperature of $200{ }^{\circ} \mathrm{C}$.

For the cement based mortars it was possible to verify a decrease in the adhesion strength of about $9 \%$ for the mortars without incorporation of PCM and 32\% for the mortars with incorporation of PCM microcapsules and fibers, when exposed to a temperature of $200^{\circ} \mathrm{C}$.
Finally, the gypsum based mortars without incorporation of PCM present a decrease of about 66\% in the adhesion strength and a decrease of about $64 \%$ for the mortars with incorporation of $40 \%$ of PCM and $1 \%$ of fibers, when exposed to a temperature of $200^{\circ} \mathrm{C}$.

According to Fig. 18, it was possible to observe that for an exposure temperature of $200{ }^{\circ} \mathrm{C}$ the better performance was presented by the cement based mortars. This result is coherent with the mechanical strengths results.

\section{Conclusion}

Based on these results, it can be concluded that the exposure to high temperatures leads to some modification in the mechanical properties of the studied mortars.

Globally, it was observed that the addition of PCM microcapsules in mortars decreases the mechanical strength for all temperature ranges studied, due to the presence of higher content of water and consequently increase in their microporosity. On the other hand, the addition of fibers in the majority of cases improves the performance of mortars, with the exception of the gypsum based mortars. This behavior can be justified by the lower adhesion of the fibers to the matrix of gypsum mortars when compared to the other binders.

The high temperatures exposure of the developed mortars results in a decrease of the flexural, compression and adhesion strengths. This behavior can be justified by the increase of the cracking phenomena during the exposure to high temperatures 
Table 8

Variation of adhesion strength at $200{ }^{\circ} \mathrm{C}$ and $600^{\circ} \mathrm{C}$, compared with exposure to $20^{\circ} \mathrm{C}$.

\begin{tabular}{|c|c|c|c|}
\hline Composition & Binder & Variation of adhesion strength at $200^{\circ} \mathrm{C}(\%)$ & Variation of adhesion strength at $600{ }^{\circ} \mathrm{C}(\%)$ \\
\hline CA500-0PCM & Aerial lime & -25 & -100 \\
\hline CA800-40PCM & Aerial lime & -63 & -100 \\
\hline CA800-40PCM-F & Aerial lime & -27 & -100 \\
\hline CH500-0PCM & Hydraulic lime & -33 & -100 \\
\hline CH500-40PCM & Hydraulic lime & -9 & -100 \\
\hline CH500-40PCM-F & Hydraulic lime & -32 & -100 \\
\hline C32.5N500-0PCM & CEM II B-L 32.5N & -66 & -100 \\
\hline C32.5N500-40PCM & CEM II B-L $32.5 \mathrm{~N}$ & -64 & -100 \\
\hline C32.5N500-40PCM-F & CEM II B-L 32.5N & -25 & -100 \\
\hline G500-0PCM & Gypsum & -63 & -100 \\
\hline G500-40PCM & Gypsum & -27 & -100 \\
\hline G500-40PCM-F & Gypsum & -33 & -100 \\
\hline
\end{tabular}
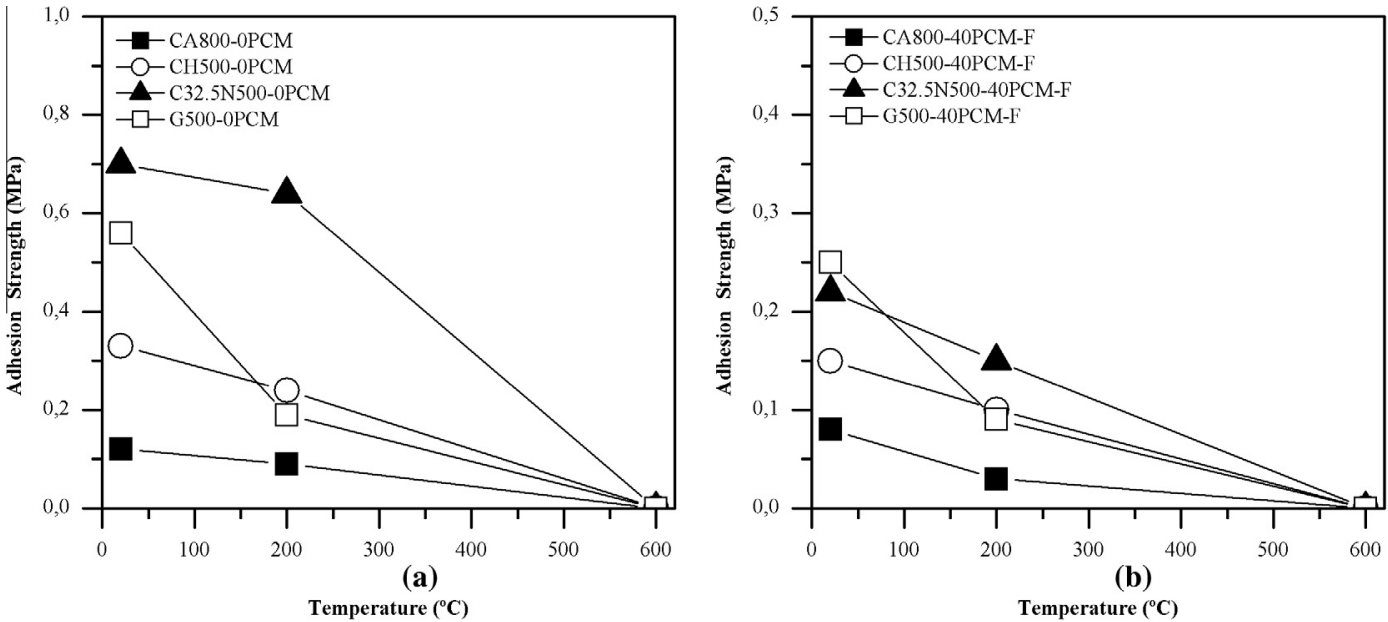

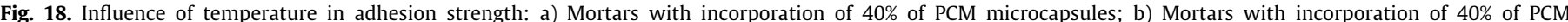
microcapsules and $1 \%$ of polyamide fibers.

caused by the stresses generated in the specimens due to expansion of the constituents. Also, there is the dehydration of some hydrated components of the mortars.

The hydraulic lime based mortars are the ones that have a lower sensitivity to high temperatures exposure, consequently presenting a better performance. Moreover, aerial lime based mortars showed a higher deterioration, presenting a sensitive behavior to high temperatures.

\section{Acknowledgement}

The authors acknowledge the Foundation for Science and Technology (FCT) for the financial support regarding PhD scholarship SFRH/BD/95611/2013.

\section{References}

[1] S.E. Kalnæs, B.P. Jelle, Phase change materials for building applications: a state-of-the-art review and future research opportunities, Energy Build. 94 (2015) 150-176.

[2] S. Bilgen, Structure and environmental impact of global energy consumption, Renew. Sustain. Energy Rev. 38 (2014) 890-902.

[3] E. Asimakopoulou, D. Kolaitis, M. Founti, Fire safety aspects of PCM-enhanced gypsum plasterboards: an experimental and numerical investigation, Fire Saf. J. 72 (2015) 50-58.

[4] Y. Zhang, G. Zhou, K. Lin, K. Zhang, H. Di, Application of latent heat thermal energy storage in buildings: state-of-the-art and outlook, Build. Environ. 42 (2007) 2197-2209.

[5] B. Zalba, J. Marín, L. Cabeza, H. Mehling, Review on thermal energy storage with phase change: materials, heat transfer analysis and applications, Appl. Therm. Eng. 23 (2003) 251-283.
[6] L. Cabeza, A. Castell, C. Barreneche, A. Gracia, A. Fernández, Materials used as PCM in thermal energy storage in buildings: a review, Renew. Sustain. Energy Rev. 15 (2011) 1675-1695.

[7] V. Tyagi, S. Kaushik, S. Tyagi, T. Akiyama, Development of phase change materials based microencapsulated technology for buildings: a review, Renew. Sustain. Energy Rev. 15 (2011) 1373-1391.

[8] G. Fang, F. Tang, L. Cao, Preparation, thermal properties and applications of shape-stabilized thermal energy storage materials, Renew. Sustain. Energy Rev. 40 (2014) 237-259.

[9] A. Athienitis, C. Liu, D. Hawes, D. Banu, D. Feldman, Investigation of the thermal performance of a passive solar test-room with wall latent heat storage, Build. Environ. 32 (1997) 405-410.

[10] L. Shilei, Z. Neng, F. Guohui, Impact of phase change wall room on indoor thermal environment in winter, Build. Environ. 38 (2006) 18-24.

[11] K. Darkwa, P. O'Callaghan, D. Tetlow, Phase-change drywalls in a passive-solar building, Appl. Energy 83 (2006) 425-435.

[12] P. Schossig, H. Henning, S. Gschwander, T. Haussmann, Micro-encapsulated phase change materials integrated in to construction materials, Sol. Energy Mater. Sol. Cells 89 (2005) 297-306.

[13] M. Ahmad, A. Bontemps, H. Sallée, D. Quenard, Thermal testing and numerica simulation of a prototype cell using light wallboards coupling vacuum isolation panels and phase change material, Energy Build. 38 (2006) 673-681.

[14] S. Cunha, J. Aguiar, V. Ferreira, A. Tadeu, Influence of the type of phase change materials microcapsules on the properties of lime-gypsum thermal mortars", Adv. Eng. Mater. 16 (2014) 433-441.

[15] T.C. Ling, C.S. Poon, Use of phase change materials for thermal energy storage in concrete: an overview, Constr. Build. Mater. 46 (2013) 55-62.

[16] F. Pacheco-Torgal, J. Faria, S. Jalali, Some considerations about the use of lime-cement mortars for building conservation purposes in Portugal: a reprehensible option or a lesser evil?, Constr Build. Mater. 30 (2012) 488-494.

[17] S. Cunha, V. Alves, J. Aguiar, V. Ferreira, Use of phase change materials microcapsules in aerial lime and gypsum mortars, Cem. Wapno Beton (Special Issue) (2012) 17-21.

[18] S. Cunha, M. Kheradmand, J. Aguiar, L. Bragança, V. Ferreira, Thermal mortars with incorporation of PCM microcapsules, Restor. Build. Monum. 19 (2013) $171-177$. 
[19] S. Cunha, J. Aguiar, V. Ferreira, A. Tadeu, Influence of adding encapsulated phase change materials in aerial lime based mortars, Adv. Mater. Res. 687 (2013) 255-261.

[20] European Committee for Standardization (CEN), EN 1015-11:1999. Methods of Test for Mortar for Masonry - Part 11: Determination of Flexural and Compressive Strength of Hardened Mortar, 1999.

[21] European Committee for Standardization (CEN), EN 1015-12:2000. Methods of Test for Mortar for Masonry - Part 12: Determination of Adhesive Strength of Hardened Rendering and Plastering Mortars on Substrates, 2000

[22] European Committee for Standardization (CEN), EN 1015-3:2004. Methods of Test for Mortar for Masonry - Part 3: Determination of Consistence of Fresh Mortar (by Flow Table), 2004.

[23] G. Vasconcelos, P.B. Lourenço, A. Camões, A. Martins, S. Cunha, Evaluation of the performance of recycled textile fibres in the mechanical behaviour of a gypsum and cork composite material, Cem. Concr. Compos. 58 (2015) 29-39.

[24] M. Lion, F. Skoczylas, Z. Lafhaj, M. Sersar, Experimental study on a mortar. Temperature effects on porosity and permeability. Residual properties or direct measurements under temperature, Cem. Concr. Res. 35 (2005) 19371942.

[25] S. Yazici, Í. Sezer, H. Sengül, The effect of high temperature on the compressive strength of mortars, Constr. Build. Mater. 35 (2012) 97-100.

[26] S. Aydin, B. Baradan, Effect of pumice and fly ash incorporation on high temperature, Cem. Concr. Res. 37 (2007) 988-995.

[27] H.F.W. Taylor, Cement Chemistry, Thomas Telford Publishing, 1997.

[28] Portuguese Institute for Quality (IPQ), NP EN 998-1:2010. Specification for Masonry Mortars. Part 1: Mortars for Interior Exteriors 2010. (in Portuguese). 